\title{
The Analysis of Legal Application on International Investment Court System under "The Belt and Road"
}

\section{Duowen Chen}

\author{
School of Law, Zhongnan University of Economics and Law, Wuhan, 430073, China
}

Keywords: The Belt and Road, Investors-national dispute settlement mechanism, International investment court system

\begin{abstract}
Under the "Belt and Road", China has a large amount of investment. According to the international investment court system of the European Union, China should be based on the "area", aim at building a multilateral investment dispute settlement mechanism, and apply it to the bilateral free trade agreement, to establish harmonious and unified characteristics of investors - national dispute settlement mechanism.
\end{abstract}

\section{Introduction}

“The Belt and Road" is a Cooperation agreement proposed by Chinese President Xi Jinping, which borrowing the history of the ancient silk road signs, relying on China and relevant countries existing multilateral mechanisms, to develop the economic partnership with the countries along the line, and jointly build the interests community, the destiny community and the responsible community of political mutual trust, economic integration and cultural inclusion.

According to the Belt and Road, China will invest heavily in countries along the Belt and Road. The continuous growth of China's national strength requires us not only to actively integrate into the world, but also to have greater power of discourse leadership and rule making. How to protect the legitimate rights and interests of investors has become an important problem to be solved. Under the bilateral and multilateral cooperation mechanisms, the establishment of a coordinated and unified international investment dispute settlement mechanism is one of the most important ways to ensure investment security and reduce investment risks. Reconstructing international investment rules is of great significance for China to continue to promote the construction of "the Belt and Road" and renew bilateral and multilateral investment rules between China and countries along "the Belt and Road". Because the countries along the road have different political, cultural, legal environment, investment credit rating and other factors, it is becoming more difficult to promote the reform and development of the investor state dispute settlement mechanism in the country along the "the Belt and Road". This paper will discuss how to reform the investor-state dispute settlement mechanism under the initiative of the Belt and Road in combination with the EU international investment court system.

\section{The Origin and Challenges of the International Investment Tribunal System}

International investment law system of the original purpose is to solve the capital exporting countries of foreign investors in capital importers of injustice suffered by bilateral investment treaties, then gradually developed to the generalized including multilateral investment agreements and contains chapter of the free trade agreement, legal system composed of a number of international investment agreements. The main purpose of the earlier international investment agreements was to protect foreign investors from the negative impact of the constantly reformed legal and policy systems of the host country during the post-colonial period, as a result of the rising economic nationalism. After the world war II, newly independent developing countries began to seize property what they thought should belong to them. The main way was to nationalize it by expropriating foreign capital. In response to the host country to collect property without compensation from damage, the 
western developed countries began to demand that parties to give up on their diplomatic protection of rights of investors, and authorized investors can under the terms of the host country in violation of the relevant investment agreement filed a compensation claim directly, lead to such investment deals in the sixties and seventies of the 20th century has been rapid development.

The European Union and the United States is the most direct investment in each other, the EU investors occupied $62 \%$ of the foreign direct investment inflows, while U.S. investors to occupy 38\% of the EU's foreign direct investment inflows. But only nine members of the European Union and the United States have BIT, investors are more willing to in the absence of protections for ISDS to invest in each other. In order to change the status, the court began to seek reform. The EU trade commissioner puts forward to establish a permanent solution and multilateral investment arbitration court appeal mechanism, as well as other possible reform measures, and these matters are public consultation is considered to be the most main areas in need of improvement. Under the commission's draft plan, the new international investment arbitration court system in the TTIP would include a court of first instance and an appellate court, and would publicly appoint qualified Judges, whose members would not belong to any government.

The introduction of an appeal mechanism for international investment disputes is also a trend of late. The driving force behind it seems to be the call for greater consistency and legitimacy in the process of decision making. The international investment arbitration tribunal also faces many challenges, such as the ambiguous qualifications of its members, the fact that investors remain the main beneficiaries of international investment agreements, the insufficient respect for the control of states parties, the neglect of the counterclaims of host countries, the nature of the award, and doubts about the implementation.

\section{The Analysis of the Legal Application of the EU International Investment Court}

\subsection{The Application of the International Investment Tribunal System Needs to Address the Issue of Legal Feasibility}

Although the EU international investment court system is a kind of "court" system which is different from the "arbitration" system, it still borrows a lot from the arbitration rules. It is mainly reflected in the following aspects. Firstly, the international investment court system uses the vocabulary of arbitration rules. Secondly, the international investment court system also borrows the existing arbitration mechanism framework. Thirdly, the specific provisions of the ICSID convention are invoked in the specific articles of the ICSID regime. A party to a dispute may also appeal if the conditions set out in article 52 of the ICSID convention are satisfied in the grounds of appeal against a decision of the court of first instance. Finally, the International Investment tribunal system provisions make the rules of arbitration applicable directly or indirectly to the tribunal, or enable the obligations of the tribunal to be applied in the arbitration system.

The above phenomena of drawing lessons from invoking, or directly applying arbitration rules in the articles of the international investment court system proposed by the EU will bring into question the "legal feasibility" of the international investment court system. The arbitration procedures of the ICSID convention can be chosen by the international investment tribunal (ICSID), thus allowing the investment tribunal's decisions to evolve into "ICSID decisions". This indicates that the TTIP draft has modified the application of the ICSID convention to some extent in bilateral agreements between the United States and the European Union. This agreement between the parties to a multilateral agreement was modified, if meet the Vienna convention on the treaty law the provisions of article 41 is feasible, according to the regulation, the bilateral agreements between the US and EU must meet the ICSID convention does not prohibit this kind of modification, and shall not affect the other parties to the convention to enjoy its rights or perform its obligations, as well as does not harm the effective implementation of the goals and objectives of the treaty.

However, the ICSID convention has been modified by the international investment tribunal system as a core element of the ICSID convention. The investment court system is in violation of the 
provisions of the International Investment tribunal system and conflict with the objective and objective of "emphasizing the convenience of international mediation or arbitration" as stated in the preamble to the convention. Moreover, allowing other ICSID members to recognize and implement ICSID decisions may be challenged as affecting the rights of other ICSID members to fulfill their obligations under the ICSID convention or the New York convention, in violation of article 41 of VCLT. Even if the ICSID arbitration rules can be invoked as an international law, the ICSID convention is unlikely to apply to all EU investors. In addition, the international investment tribunal system, based on the TTIP of a bilateral agreement, cannot guarantee recognition and implementation of decisions in territories other than those of the parties. Since the relevant third party may be a member of the New York convention or ICSID convention, but not of TTIP, the ruling will not be binding on it.

At the same time, the European court of international investment system and investment system of court under the bilateral agreement might increase the investment of fragmentation, with a complete reversal of the court system before the arbitration system, may increase the cost of time and money of case treatment, the court is likely to be more national institutions, investors may therefore give up adopting this kind of investment disputes settlement, etc. Therefore, the EU's international investment court system should be well implemented and applied, and the prerequisite of legal feasibility should be solved.

\subsection{The International Investment Tribunal System Is Applicable to the Legal Feasibility Analysis of "The Belt and Road"}

There are different views on the Belt and Road initiative. Some people believe that the construction of "the Belt and Road" is not based on international treaties, but more on a "policy governance" model, focusing on "One-way and real benefit", which is different from the "rule governance" model with the explicit equivalence of rights and obligations. This "policy governance" model has the problem of insufficient regulation. Some scholars also pointed out that there were serious differences in domestic legislation and participation in international investment dispute settlement mechanisms such as ICSID. Therefore, promoting the development of bilateral investment treaties between China and countries along "the Belt and Road" and improving the legal framework of regional cooperation are important means to improve the legal environment of "the Belt and Road". The author thinks that, although the EU creatively put forward the system of international investment, the court, but to use this system to China and countries along the "area" investors - dispute settlement mechanism of the country, there are many quote, reference or directly apply to the ICSID convention or the New York convention, the court system for the international investment in the "area" all the way along the country's laws apply caused difficulties.

Similarly, since not all countries along "the Belt and Road" have acceded to the ICSID convention and the New York convention, this has created obstacles to the recognition and implementation of investment arbitration cases. There are various economic, trade and political regional organizations such as ASEAN, the European Union, CIS and Opec along "the Belt and Road". There may be two problems here: one is how China should establish an investment court system with these regional organizations, and the other is how to guarantee the national regulatory rights of members in the region if an investment court system is established with regional organizations. Thirdly, if a system of international investment tribunals with bilateral agreements is established along the "the Belt and Road", it will lead to the emergence of several international investment tribunals in the region. For example, between the investment court and the investment court in the area along "the Belt and Road”, can the decision of the court bind the b court, or become a precedent for the b court to refer to? How to ensure the predictability of the investment dispute settlement mechanism, if the two courts disagree on the investment dispute adjudication of the same case? These are the inevitable "fragmentation" issues under bilateral trade agreements, which will have a significant impact on the legitimacy, predictability and dispute resolution efficiency of the case.

Therefore, such arrangements may not achieve justice and efficiency. Because the investor state dispute settlement mechanism has the participation of the main body of the government. In addition 
to judges of third country nationality, for the other two judges, the judges of host country nationality are likely to be more inclined to safeguard the public interest or national security of their own country. Judges of the same nationality as investors are also more likely to defend the rights and interests of investors in their own countries from the perspective of investors. The court of first instance gave its main discretion to the judges of the nationality of a third country, and the judges of the nationality of a third country did not understand the value to be realized by the dispute measures implemented by the host country, making it more difficult to achieve the purpose of accurate judgment. Under the TTIP draft, a permanent court of appeal will be set up, in a largely similar format to the court of first instance, with six judges. Two judges of the nationality of the parties to the bilateral investment agreement and two judges of the nationality of the third state. Such arrangements could also evolve into more country-friendly courts, allowing investors to abandon the so-called International Investment Tribunal and seek other arbitrators to rule.

\section{Safeguard the Power of Regulation along the Country along “The Belt and Road"}

The establishment of a unified regional investor-state dispute settlement mechanism in countries along the "the Belt and Road" is one of the main problems in the existing investor-state dispute settlement mechanism. Doubters argue that the regulatory authority that the host country should have for the national public interest and sustainable development is limited and deprived under the existing investor-state dispute settlement mechanism. How to ensure that the regulatory power of countries along "the Belt and Road" will not be restricted and affected by the existence of future multilateral investor-state dispute settlement mechanism is also a problem that must be analyzed in advance.

In this issue, we can learn from the EU's practice in the international investment court system from two aspects. First, the article stipulates that the investment court shall be limited in the judicial power to interpret international treaties. The international investment tribunal can consider only member national law as a matter of fact. In accordance with the provisions of the draft TTIP, the international investment tribunal shall make its decisions in accordance with this agreement or other rules of international law between members. The court may interpret the law in accordance with VCLT international public law interpretation habits. However, the member's domestic law could not be considered as applicable law but only as a "fact". These provisions clearly show that the investor-state dispute settlement mechanism cannot restrict and restrict the domestic law, let alone explain the domestic law. On the other hand, legal remedies for international investment disputes are generally limited to compensation or compensation. In the EU's international investment court system, investment courts can rule only on matters such as monetary compensation or restitution. Moreover, the EU's international investment court system explicitly prohibits the tribunal from "abolishing, suspending or amending" the host country's treatment of investors. This, on the other hand, limits the intervention of the international investment tribunal in the regulatory authority of the host country.

The international investment tribunal system also maintains the regulatory authority of the host country by clarifying or limiting the interpretation of some concepts in international investment law. For example, the traditional international investment law lacks clear provisions on "fair and just treatment", and the tendency of "fair and just treatment" is widely interpreted in international investment arbitration cases, which makes it easier for investors to use "fair and just treatment" to claim and interfere with the regulation right of the host country. In order to solve this problem, the EU, in the international investment law system, has tried to limit the space for interpretation, clarify and improve the protection standards. Fair and fair treatment is limited to a closed list that is consistent with the European Union's preconceived notions. However, this level of clarification alone may not be enough. Because the EU's investment court system makes "clear arbitrariness" an essential element of "fair and equitable treatment". Both "obvious" and "arbitrary" have a lot of explaining to do. Neither the arbitral tribunal nor the investment court has a substantive element to assess what constitutes "clear arbitrariness". If further clarification of the matter is provided by subsequent agreements, "untrustworthy" or "unreasonable" may be introduced to further examine "apparent 
arbitrariness". In a word, the EU international investment court system can provide many useful references and references for China to improve the "The Belt and Road" investor-state dispute settlement mechanism.

\section{Conclusion}

"The Belt and Road" and the establishment of the rule of law in the context of global governance by multilateral investors-national dispute settlement mechanism should take the international social contract as the key and adhere to the "rule-oriented" principle as the core. The establishment of a multilateral investment dispute settlement rules need step by step. We must first improve and update our investors in the countries along the "area" - the terms of the dispute settlement mechanism of the country. In order to realize the multilateral investors - build national dispute settlement mechanism, also needs to coordinate all the way "area" along the country's regulatory authority and regional legal order, to limit the power of the court interpretation of investment treaty, so as to ensure that the host country for the regulation of national security, public interests, rights deprived and restricted.

\section{References}

[1] Duan F, Ji Q, Liu B Y, et al. Energy investment risk assessment for nations along China’s Belt \& Road Initiative[J]. Journal of Cleaner Production, 2018, 170: 535-547.

[2] Chen J, Wu H, Qian H, et al. Challenges and prospects of sustainable groundwater management in an agricultural plain along the Silk Road Economic Belt, north-west China[J]. International Journal of Water Resources Development, 2018, 34(3): 354-368.

[3] Huang Y, Fischer T B, Xu H. The stakeholder analysis for SEA of Chinese foreign direct investment: the case of 'One Belt, One Road'initiative in Pakistan[J]. Impact Assessment and Project Appraisal, 2017, 35(2): 158-171.

[4] Lostal M, Vilaça G V. The Bamiyazation of cultural heritage and the Silk Road economic Belt: Challenges and opportunities for China[J]. The Chinese Journal of Comparative Law, 2015, 3(2): 329-347. 